\title{
A CLINICAL STUDY ON SURGICAL MANAGEMENT OF DIAPHYSEAL FRACTURE OF FEMUR WITH CLOSED INTRAMEDULLARY INTERLOCKING NAIL
}

\author{
Chanappa T. S1, H. B. Shivakumar², Rakesh Mohan R ${ }^{3}$
}

\section{HOW TO CITE THIS ARTICLE:}

Chanappa T. S, H. B. Shivakumar, Rakesh Mohan R. “A Clinical Study on Surgical Management of Diaphyseal Fracture of Femur with Closed Intramedullary Interlocking Nail". Journal of Evolution of Medical and Dental Sciences 2014; Vol. 3, Issue 10, March 10; Page: 2508-2518, DOI: 10.14260/jemds/2014/2165

ABSTRACT: BACKGROUND: Intramedullary interlocking is currently considered the treatment of choice for femoral shaft fractures, with high rates of fracture union, advantage of early stabilization which decreases the morbidity and mortality rate in patients, allows early mobilization, reduces the incidence of infection, malunion, non-union or implant failure. AIMS: To assess the time taken for fracture union and the functional outcome in patients with fracture shaft of femur. METHODS AND MATERIALS: We studied a total of 30 patients of fracture shaft of femur admitted in the Orthopedic Department of Kempegowda Institute of Medical sciences Bangalore treated with closed intramedullary interlocking nailing. 23 patients were male and 7 were females and age group ranged from 18-49 years with mean age 30 Yrs. right side fractures encountered in 18 cases and 12 left side. 24 fractures were closed and 6 fractures were open type. 5 fractures were in proximal third, 19 fractures were in the middle third and 6 in distal third of femur. Duration of study was 2 years. RESULTS: Duration between injury and surgery was <24 Hours in 6.67\%, 24-72 hours in 50\% and 47 Days in 43.3\%. Duration of hospital stay was average 11.43 days ranging from 06-22days. Mean time for union was 21.3 weeks ranging from 16-32weeks. There were two cases of superficial infection and no deep infection. Excellent to Good result was seen in 90\% cases. CONCLUSION: We conclude that closed intramedullary interlocking nailing after is an excellent technique for the treatment of femoral shaft fracture. It is an excellent mode for treatment of complex, comminuted and unstable femoral fracture. It reduces the incidence of malunion and maintains length of the bone, also enables early mobilization \& return to routine activities.

KEYWORDS: Fracture; shaft; femur; closed; interlocking; intramedullary; nail; diaphyseal.

INTRODUCTION: Orthopaedic surgeons often encounter diaphyseal femur fracture as a result of road traffic accidents. Most of these fractures often result from high energy trauma; one must have a high index of suspicion for complications or other injuries. Fracture femur results from the drawbacks of fast life and violence. They are major source of mortality and morbidity in patients with such injury.

The art of femoral fracture care is a constant balancing of the often conflicting goals of anatomical alignment and early functional rehabilitation of limb. In addition, there can be difficulty in assessing malrotation at the fracture site. They can be life threatening, because of open wounds, hemorrhagic shock, fat embolism, ARDS or multiple organ failure.

AIMS AND OBJECTIVES: To evaluate the functional outcome of fractures of the shaft of the femur treated with closed intramedullary interlocking nailing.

1) Early mobilization, to prevent fracture disease and enhance fracture healing. 
2) To prevent rotational deformity.

3) Also to study the

a) Intra-operative difficulties and complications.

b) Post-op complications.

c) Time to fracture union.

d) Period of ambulation.

e) Range of motion.

METHODOLOGY: The present study was carried out between November 2011 and November 2013 in Kempegowda Institute of Medical Sciences. Antegrade nailing using the Standard intramedullary interlocking nail was performed on 30 cases who presented with shaft fractures of the femur.

\section{INCLUSION CRITERIA:}

- Age group >18yrs.

- Acute isolated fracture involving the diaphysis of femur.

- Closed \&Grade I, II Gustillo Anderson compound fracture.

- Segmental fracture.

- All Comminuted fracture (Winquist Hansen classification)

\section{EXCLUSION CRITERIA:}

- Age group $<18$ yrs.

- Grade-III Gustillo Anderson compound fracture.

- Associated with Head injury.

- Associated fractures in any of the 4 limbs.

- Pathological Fractures, Fracture Non-Union \& Delayed Union.

- Patient not willing or medically unfit for surgery.

Patients admitted with fractures of shaft of femur after meeting inclusion and exclusion criteria are selected for study. After clinical assessment of signs and symptoms, $\mathrm{x}$ rays and pre- operative investigations are done

After prior informed consent, a pre-operative anesthetic evaluation is done, pre-op planning of fixation is made and nail length is measured.

Under anesthesia, closed reduction and internal fixation with intramedullary interlocking nails done using c-arm.

Post-operatively mobilized without weight bearing on $2^{\text {nd }}$ to $4^{\text {th }}$ day, patients are advised active quadriceps exercises, Hip and knee flexion-extension exercises. Partial weight bearing started at 6 weeks. Full weight bearing was possible by 8-12 weeks depending on the fracture configuration, callus response.

Assessment was done at regular intervals of 6weeks, 12 weeks and 6 months. At each followup visit, patient is evaluated clinically, radiologically and complications are noted.

Based on these data the final outcome is assessed according to Thoresen et al criteria. ${ }^{1}$ 
ETHICS: Since closed intramedullary interlocking nailing of femur is worldwide accepted procedure so there are no ethical issues associated with the procedure .A prior informed written consent is taken for surgery and anesthesia.

\section{RESULTS:}

\begin{tabular}{|c|c|c|c|c|}
\hline $\begin{array}{c}\text { AGE } \\
\text { (years) }\end{array}$ & MALE & PERCENTAGE (\%) & FEMALE & PERCENTAGE (\%) \\
\hline $18-29$ & 12 & 40 & 3 & 10 \\
\hline $30-39$ & 9 & 30 & 1 & 3.33 \\
\hline $40-49$ & 2 & 6.67 & 3 & 10 \\
\hline \multicolumn{5}{|c|}{ Age Distribution } \\
\hline
\end{tabular}

\begin{tabular}{|c|c|c|}
\hline SEX & CASES & PERCENTAGE \\
\hline MALE & 23 & 76.7 \\
\hline FEMALE & 7 & 23.3 \\
\hline \multicolumn{3}{|c|}{ Sex Distribution } \\
\hline
\end{tabular}

\begin{tabular}{|c|c|c|}
\hline MODE OF INJURY & CASES & PERCENTAGE \\
\hline RTA & 26 & 86.67 \\
\hline FALL & 4 & 13.33 \\
\hline \multicolumn{2}{|c|}{ Mode of Injury } \\
\hline
\end{tabular}

\begin{tabular}{|c|c|c|}
\hline SIDE INCIDENCE & CASES & PERCENTAGE \\
\hline RIGHT & 18 & 60 \\
\hline LEFT & 12 & 40 \\
\hline
\end{tabular}

Side Incidence

\begin{tabular}{|c|c|c|}
\hline TYPE OF FRACTURE & NUMBER OF CASES & PERCENTAGE \\
\hline CLOSED/SIMPLE & 24 & 80 \\
\hline OPEN/COMPOUND & 6 & 20 \\
\hline \multicolumn{2}{|c}{ Type of Fracture } \\
\end{tabular}

\begin{tabular}{|c|c|c|}
\hline $\begin{array}{c}\text { LEVEL OF } \\
\text { FRACTURE }\end{array}$ & $\begin{array}{c}\text { NUMBER OF } \\
\text { CASES }\end{array}$ & PERCENTAGE \\
\hline PROXIMAL $1 / 3^{\mathrm{RD}}$ & 5 & 16.67 \\
\hline MIDDLE $1 / 3^{\mathrm{RD}}$ & 19 & 63.33 \\
\hline LOWER $1 / 3^{\mathrm{RD}}$ & 6 & 20 \\
\hline \multicolumn{3}{|c}{ Level of Fracture } \\
\hline
\end{tabular}




\section{ORIGINAL ARTICLE}

\begin{tabular}{|l|c|c|}
\hline FRACTURE PATTERN & NO OF CASES & PERCENTAGE \\
\hline COMMUNITED & 14 & 46.67 \\
\hline TRANSVERSE & 9 & 30 \\
\hline OBLIQUE & 3 & 10 \\
\hline SPIRAL & 4 & 13.33 \\
\hline
\end{tabular}

Fracture Pattern

\begin{tabular}{|c|c|c|c|c|c|}
\hline $\begin{array}{c}\text { NAIL } \\
\text { DIAMETER } \\
(\mathrm{mm})\end{array}$ & $\begin{array}{l}\text { NUMBER OF } \\
\text { CASE }\end{array}$ & $\begin{array}{c}\text { PERCENTAGE } \\
\text { (\%_) }\end{array}$ & SEX & $\begin{array}{l}\text { NUMBER } \\
\text { OF CASE }\end{array}$ & $\begin{array}{c}\text { PERCETAGE } \\
(\%)\end{array}$ \\
\hline \multirow{2}{*}{9} & \multirow{2}{*}{6} & \multirow{2}{*}{20} & MALE & 0 & 0 \\
\hline & & & FEMALE & 6 & 20 \\
\hline \multirow{2}{*}{10} & \multirow{2}{*}{18} & \multirow{2}{*}{60} & MALE & 17 & 56.67 \\
\hline & & & FEMALE & 1 & 3.33 \\
\hline \multirow{2}{*}{11} & \multirow[t]{2}{*}{6} & \multirow{2}{*}{20} & MALE & 6 & 20 \\
\hline & & & FEMALE & 0 & 0 \\
\hline
\end{tabular}

Nail Diameter

\begin{tabular}{|c|c|c|c|c|c|}
\hline $\begin{array}{l}\text { NAIL SIZE -LENGTH } \\
(\mathrm{mm})\end{array}$ & $\begin{array}{c}\text { NUMBER } \\
\text { OF } \\
\text { CASE }\end{array}$ & PERCENTAGE & SEX & $\begin{array}{c}\text { NUMBER } \\
\text { OF } \\
\text { CASE }\end{array}$ & PERCETAGE (\%) \\
\hline \multirow{2}{*}{360} & \multirow[t]{2}{*}{ 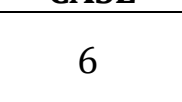 } & \multirow{2}{*}{$20 \%$} & MALE & 1 & 3.33 \\
\hline & & & FEMALE & 5 & 16.67 \\
\hline \multirow{2}{*}{380} & \multirow{2}{*}{8} & \multirow{2}{*}{$26.67 \%$} & MALE & 6 & 20 \\
\hline & & & FEMALE & 2 & 6.67 \\
\hline \multirow{2}{*}{400} & \multirow[t]{2}{*}{10} & \multirow{2}{*}{$33.33 \%$} & MALE & 6 & 20 \\
\hline & & & FEMALE & 4 & 13.33 \\
\hline \multirow{2}{*}{420} & \multirow{2}{*}{4} & \multirow{2}{*}{$13.33 \%$} & MALE & 4 & 13.33 \\
\hline & & & FEMALE & 0 & 0 \\
\hline \multirow{2}{*}{440} & \multirow{2}{*}{2} & \multirow{2}{*}{$6.77 \%$} & MALE & 2 & 6.67 \\
\hline & & & FEMALE & 0 & 0 \\
\hline
\end{tabular}

\begin{tabular}{|c|c|c|}
\hline WEEKS & $\begin{array}{c}\text { PARTIAL WEIGHT } \\
\text { BEARING }\end{array}$ & $\begin{array}{c}\text { FULL WEIGHT } \\
\text { BEARING }\end{array}$ \\
\hline $6-12$ & 21 & 0 \\
\hline $13-16$ & 09 & 21 \\
\hline $17-20$ & 0 & 09 \\
\hline \multicolumn{2}{|c|}{} \\
\hline
\end{tabular}




\begin{tabular}{|c|c|c|}
\hline WEEKS & NUMBER OF CASES & PERCENTAGE \\
\hline $12-16$ & 5 & 16.67 \\
\hline $17-20$ & 14 & 46.67 \\
\hline $21-24$ & 9 & 30 \\
\hline$>24$ & 2 & 6.67 \\
\hline \multicolumn{2}{|c|}{ Radiological Fracture Union } \\
\hline
\end{tabular}

\begin{tabular}{|l|c|c|}
\hline \multicolumn{1}{|c|}{ Complication } & $\begin{array}{c}\text { No. of } \\
\text { Patients }\end{array}$ & Percentage \\
\hline Fat Embolism & 2 & $6.67 \%$ \\
\hline Superficial infections & 2 & $6.67 \%$ \\
\hline Delayed union & 2 & $6.67 \%$ \\
\hline $\begin{array}{l}\text { Restriction of movement } \\
\text { at Knee joint (in degrees) }\end{array}$ & 3 & $10 \%$ \\
\hline $91-120$ & 2 & $6.67 \%$ \\
\hline$<90$ & 2 & $6.67 \%-$ \\
\hline Shortening 1cm & 1 & $3.3 \%$ \\
\hline$>1-2 \mathrm{~cm}$ & Complications \\
\hline \multicolumn{2}{|c|}{} \\
\hline
\end{tabular}

No cases of breakage of screws/ nail, deep infections, nonunion and implant failure were noted in our study series.

\begin{tabular}{|c|c|c|}
\hline FUNCTIONAL OUTCOME & NUMBER OF CASES & PERCENTAGE \\
\hline EXCELLENT & 23 & $76.67 \%$ \\
\hline GOOD & 4 & $13.33 \%$ \\
\hline FAIR & 3 & $10 \%$ \\
\hline POOR & 0 & 0 \\
\hline Functional Outcome - According to Thoresen et al scoring system
\end{tabular}




\section{ORIGINAL ARTICLE}

\section{ILLUSTRATION- 1:}

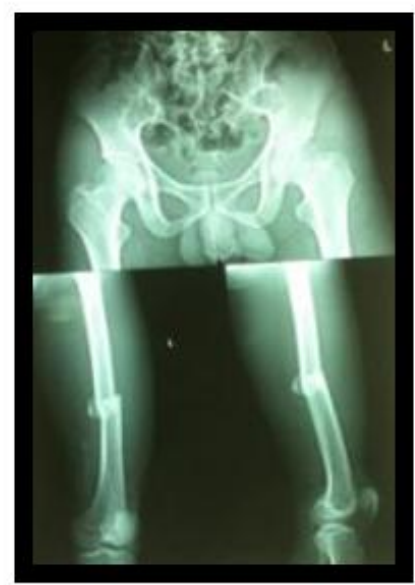

PRE-OP

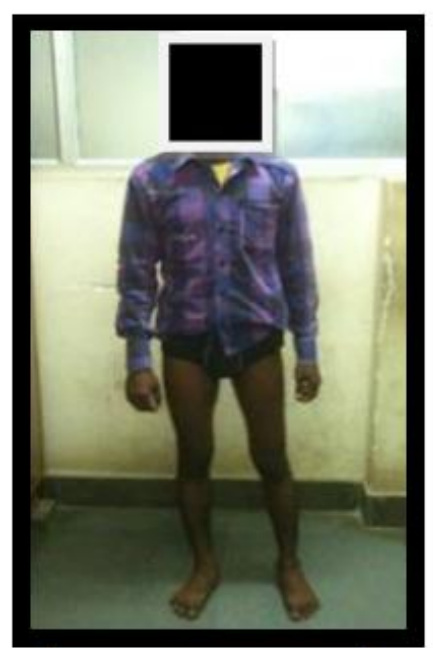

FULL WEIGHT

Hip- Extension

Knee- Extension

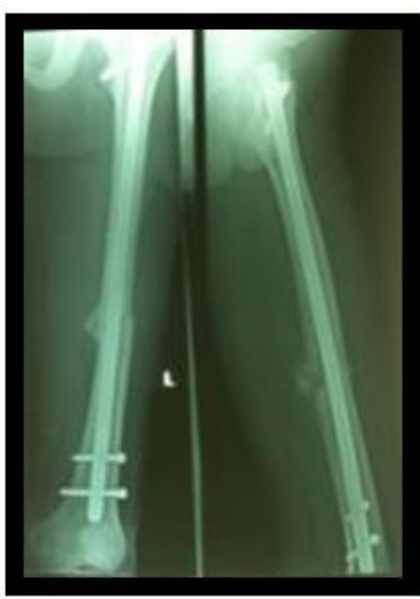

IMMEDIATE POST-OP

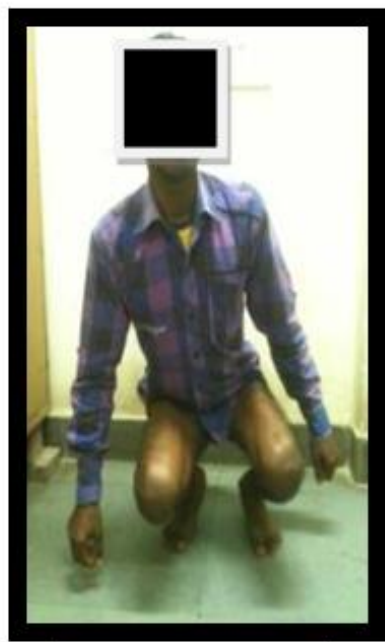

SQUATTING

Hip- Flexion

Knee- Flexion

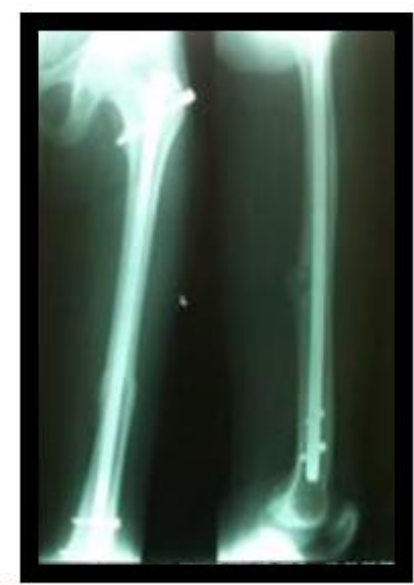

6 MONTHS FOLLOWUP

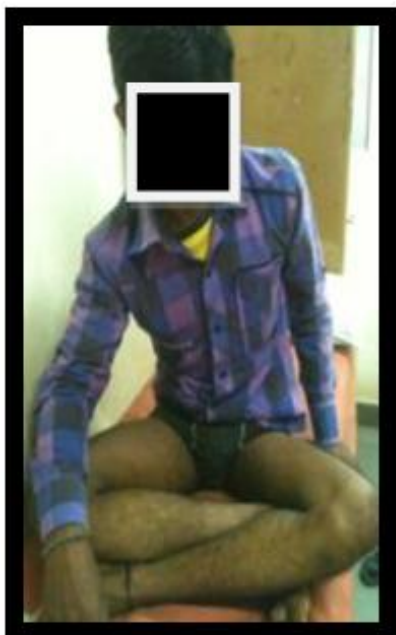

SITTING CROSSLEGGED

Hip- Flexion

Abduction

External rotation

Knee- Flexion 


\section{ORIGINAL ARTICLE}

\section{ILLUSTRATION 2}

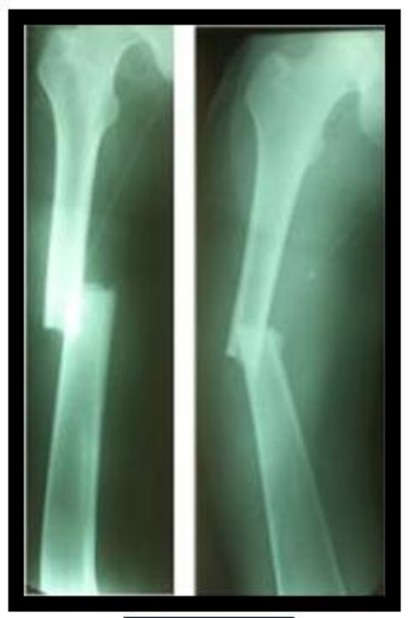

PRE-0P

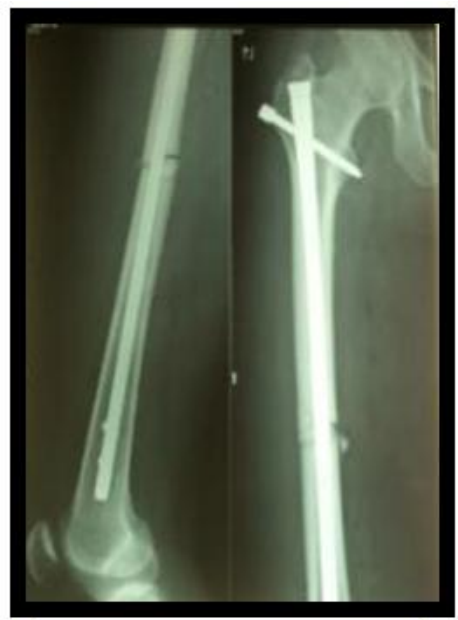

IMMEDIATE POST-OP

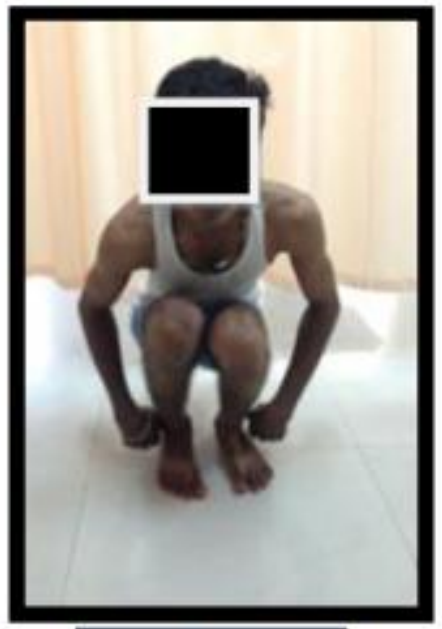

\section{SQUATTING}

Hip- Flexion

Knee- Flexion

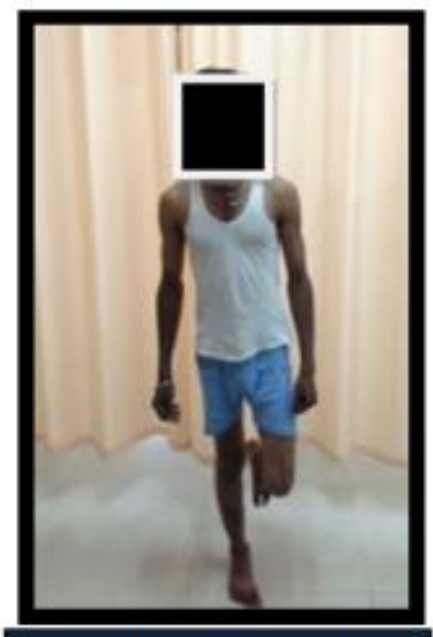

FULL WEIGHT BEARING

Hip- Extension

Knee- Extension

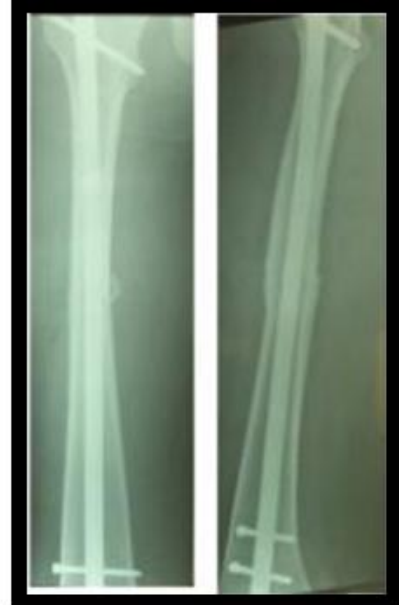

6 MONTHS FOLLOWUP

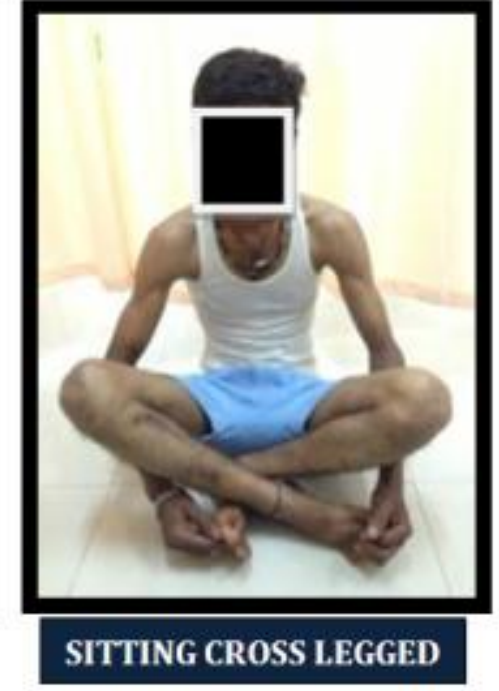

Hip- Flexion Abduction

External rotation

Knee- Flexion

DISCUSSION: The treatment of fracture diaphysis of femur has evolved from the old conservative management to the most recent methods of interlocking nails. This is the era of biological fixation. Interlocking nails have greatly expanded the indications for closed IM nailing of femoral fractures. The rationale for internal fixation is that it restores the anatomical alignment and allows early mobilization of the patient and limb.

The use of a plate to achieve osteosynthesis necessitates wide operative exposure and excessive soft tissue stripping, resulting in increased blood loss and operating time. The risk of infection is 
increased. Failure of the plate is common and the need for primary bone grafts adds additional morbidity to the procedure.

Early mobilization following fractures of the femoral diaphysis has been shown to have a significant advantage in terms of both joint mobility and economic impact which has very well attained by the use of interlocking nails.

AGE INCIDENCE: Majority of our patients were in the age group 18-29 years which is the Prime earning group in the Indian families. The mean age was 30years in our current study.

In the study of Wiss et.al mean age was 29 year ${ }^{1}$.

Series of Thoresen of 48 cases of femoral shaft fractures stated a mean age of 28 years ${ }^{2}$.

White et al observed mean age of 28 years in their study 3 .

Most of the patients were manual laborers and agriculturist whose early return to work was important.

SEX INCIDENCE: In most of the studies and in ours too the incidence was significantly higher in males. (23 males and 7 females).

Wiss - Fleming et.al Male predominance (83.7\%) found in his 111 patients series.

Alho et al reported 55\% male predominance in 120 patients. ${ }^{4}$

SIDE INCIDENCE: In the series of Johnson and Greenberg right side was predominantly involved 5 . In the series of Wiss et al of comminuted fractures right side was predominantly involved ${ }^{1}$.

MODE OF INJURY: The mode of injury in this series we had 26 cases of road traffic accident i.e. around $86.67 \%$. The incidence of road traffic accident has been on the increasing scale.

Winquist et $\mathrm{al}^{6}$ also had $77 \%$ of cases because of motor vehicular accidents.

This observation by various authors implies that fracture shaft femur is usually a result of high energy trauma. So it is commonly associated with other injuries.

FRACTURE PATTERN: In the study of Thoresen et.al comminuted fractures were the commonest followed by the transverse and then the spiral pattern.

In the series of Wiss et al comminuted fractures predominated. ${ }^{1}$

In our series, $63.33 \%$ of fractures were located in the middle third, while in reported series of conventional nailing, this figure ranged from $60-80 \%$ and $50 \%$ in the series of Thoresen et al, where G.K. interlocking nail was used. Even the distribution of both comminution and type of fracture is similar to those in other series, where in interlocking nails were used showed comminuted.

TIME FROM INJURY TO SURGERY: Interval between injury and surgery in our series was between 3 to 10 days. Average 2.83 days. The compound fracture (Grade II) was thoroughly debrided and open interlocking was done in the same setting. Blumberg et al reported that time from injury to surgery in their series was an average of 3.5 days. $^{7}$

TIME DURATION OF HOSPITAL STAY: The average time of hospital stay in our study was an average of 11.43 days, compared to Wiss et al 12 days. $^{1}$ 


\section{AVERAGE TIME FOR UNION:}

The average time for union in our series was 21.3 weeks ranging from 16 - 24 weeks.

Gross Kempf et al, (1985) reported union at 18 weeks, Thoresen et al, (1985) at 16 weeks, Wiss et al (1986) obtained at 26 weeks. ${ }^{1,2,8}$

COMPLICATIONS: The incidence of infection following open nailing was reported by Wiss et al as $8.3 \%$ and by John et al as $13 \%$. The incidence of infection was drastically low in closed interlocking.

2 cases of Fat Embolism were encountered one preoperative and another immediate postoperatively. Both patients recovered within 48-72 hours with supplementary oxygen, fluid management, steroid therapy, none required invasive ventilation.

In our series there were 2 cases with superficial infection and no case of deep infection. The case was managed with antibiotics did not need any surgical intervention.

SHORTENING: One of the most common complication following fracture diaphysis femur has been shortening at the fracture site. Interlocking IM nail has virtually eliminated this complications or at least got down its incidence immensely.

In our series shortening of between 1-2 $\mathrm{cm}$ was seen in 3 patients. Hansen ST Jr and Lhowe reported significant shortening in $7 \%$ cases. $^{9}$

FUNCTIONAL OUTCOME: The functional outcome in our present study was $90 \%$ for excellent and good results.

\begin{tabular}{|c|c|}
\hline STUDY & $\begin{array}{c}\text { PERCENTAGE OF } \\
\text { EXCELLENT/GOOD RESULT }\end{array}$ \\
\hline PRESENT STUDY & 90 \\
\hline Johnson et $\mathrm{al}^{4}$ & 96.1 \\
\hline Gross Kempf et al ${ }^{6}$ & 90 \\
\hline Wiss et al ${ }^{1}$ & .92 \\
\hline Klauss et al 10 & 97 \\
\hline
\end{tabular}

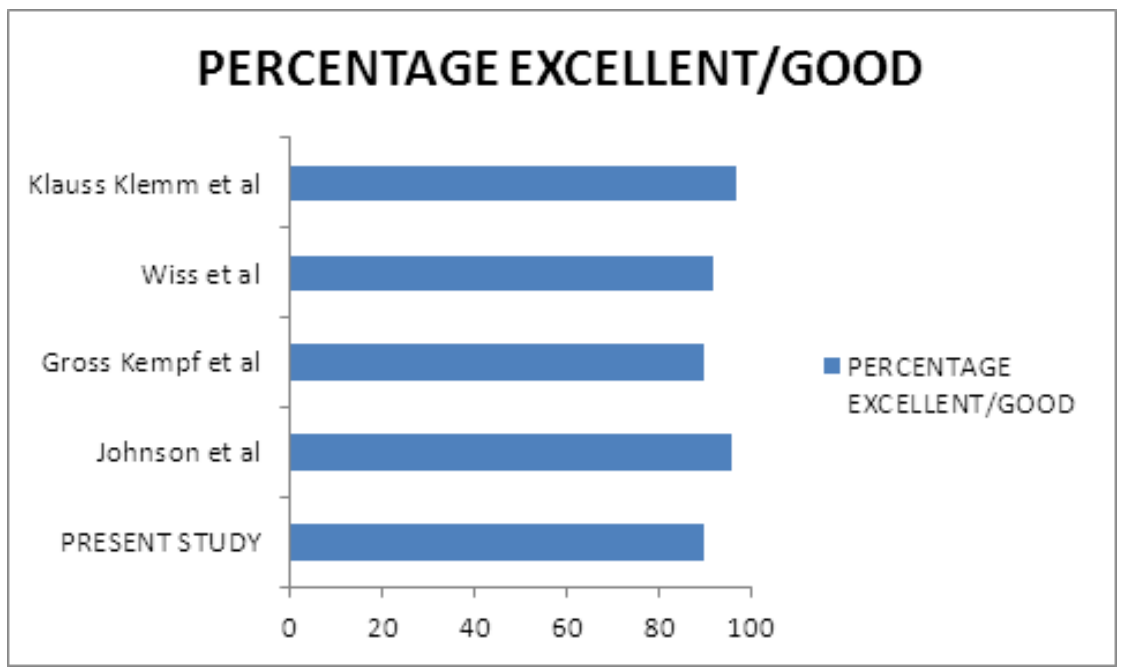




\section{COMPARATIVE STUDIES:}

\begin{tabular}{|l|c|c|c|c|c|}
\hline & $\begin{array}{c}\text { Number } \\
\text { of cases }\end{array}$ & $\begin{array}{c}\text { Duration of } \\
\text { Hospital stay }\end{array}$ & $\begin{array}{c}\text { Shortening } \\
\mathbf{> 1} \mathbf{c m} \%\end{array}$ & $\begin{array}{c}\text { Union } \\
\text { weeks }\end{array}$ & $\begin{array}{c}\text { Deep } \\
\text { Infection\% }\end{array}$ \\
\hline Present study & 30 & 11.43 & 10 & 21.3 & 0 \\
\hline Thoresen et al $^{2}$ & 48 & - & 7.5 & 16 & 0 \\
\hline Gross Kempf et al $^{6}$ & 49 & 21 & 7.5 & 18 & 2.1 \\
\hline Winquist \& Hansen $^{5}$ & 245 & 26 & 7.3 & 14 & 0.4 \\
\hline
\end{tabular}

CONCLUSION: Closed Intramedullary interlocking nailing is a very effective, successful and time tested method of treatment for diaphyseal fractures of femoral shaft.

It is advantageous over other methods of treatment because:

- Fracture hematoma not disturbed.

- Fracture site vascularity not further hampered.

- Stable fixation.

- Faster rate of fracture union.

- Lower rate of complications like infection \& non-union.

- Allows early mobilization \& return to routine activities.

\section{REFERENCES:}

1. Wiss DA, Christopher H, Fleming, Hoel M, Matta, Douglas C. Comminuted and Rotationally unstable fractures of the Femur treated with an interlocking nail. 1986; 212: 35-47.

2. Thoresen BO, Antti A, Ekeland A, Stromsoe K, Folleras P, Haukebo A. Interlocking Intramedullary Nailing in Femoral Shaft Fractures. J Bone Joint Surg 1985; 67(A):1313-1320.

3. Brumback RJ, Smith J, White.P. Pudendal N. Palsy complication in nailing of femur; J Bone Joint Surg 1992; 74(A):1450-1455.

4. Alho A, Stromsoe K, Ekeland A. Locked intramedullary nailing of femoral shaft fractures. Journal of trauma, 1991;31: 49-59.

5. Johnson K, Tenser A, Sherman M. Biomechanical considerations in intramedullary techniques. J of Orthopaedics, 1988;3: 1-5

6. Winquist RA and Hansen ST. Communuted fractures of the femoral shaft treated by intramedullary nailing. Orthop Clin North Am, 1980; 11: 633.

7. Blumberg KD, Foster WC, Blumberg JF. A comparison of Brooker Wills \& Russel Taylor nails for treatment of fracture femoral shaft. J. Bone Joint Surg Am., Aug 1990; 72A:1019-1024.

8. Kempf I, Grosse A, Lafforgned L. Locking in Interlocking Nail. Clin. Orthop.1986; 212:211-219.

9. Hansen ST Jr and Lhowe DW. Diaphyseal fractures of the femur. Operative Orthopedics, 2nd Edn., Chapman MW, JB Lippincott Company, 1993; 637-650.

10. Klemm KW and Borner M. Interlocking nailing of complex fractures of the femur and tibia. Clin Orthop, 1986; 212: 89-100. 


\section{ORIGINAL ARTICLE}

\section{AUTHORS:}

1. Chanappa T. S.

2. H. B. Shivakumar

3. Rakesh Mohan R.

\section{PARTICULARS OF CONTRIBUTORS:}

1. Associate Professor, Department of Orthopaedics, Kempegowda Institute of Medical Sciences, Bangalore.

2. Professor, Department of Orthopaedics, Kempegowda Institute of Medical Sciences, Bangalore.

3. IIIrd Year Post Graduate, Department of Orthopaedics, Kempegowda Institute of Medical Sciences, Bangalore.

\section{NAME ADDRESS EMAIL ID OF THE} CORRESPONDING AUTHOR:

Dr. Rakesh Mohan R, \#27, Rajasree Bhavan, $1^{\text {st }}$ Cross, Bharathi Layout, S. G. Palaya, Bangalore - 560029, Karnataka.

E-mail: drrakeshmohan@gmail.com

Date of Submission: 27/01/2014.

Date of Peer Review: 28/01/2014.

Date of Acceptance: 15/02/2014.

Date of Publishing: 05/03/2014. 